\title{
COMPUTERIZING CELTIC KINGS AND CLERICS: \\ TOWARDS A PROSOPOGRAPHY \\ OF EARLY MEDIEVAL IRELAND
}

\section{DAVID E. THORNTON}

It is perhaps self-evident that the prosopographical study of the elites of any historical society is dependent partly upon the political and social structures characteristic of that society and partly upon the nature and content of the relevant primary sources. However, when studying the prosopography of the early medieval Insular Celtic peoples, this point is especially meaningful. This article reviews the recent research for the early medieval Celts (and especially, the Irish) and outlines possible avenues for future research in the light of a brief commentary on the socio-political structures and a description of the pertinent primary sources. The second half of the article will briefly describe an automated prosopographical database on which compilation has started and also sketch its prospective development in the future.

At the outset, it can be stated that prosopography has not figured as significantly in medieval Celtic studies as it has for other parts of Europe during the early and high Middle Ages, and especially not with reference to computers. Indeed, it would probably not be inaccurate to suggest that searches of the International Medieval Bibliography CD-ROM using the title keywords 'Celtic' (or 'Ireland', 'Wales', etc.) and 'prosopography' would generate very few hits. Of course, as will be indicated below, Celtic historians have engaged in certain fields of study which can be considered part of the prosopographical approach - for example, genealogy and kinship, onomastics, inheritance and succession, etc. - but these are yet to be incorporated into a fuller, comprehensive prosopography of medieval Celtic elites. This is not to suggest that prosopographical studies are not possible for the Celts - far from it - nor that Celtic historians are not unaware of the possibilities, and there are very recent indications that this deficiency is currently being rectified.

During the period $c .500-c .1100$, the elites of what are now Ireland, Scotland and Wales were predominantly royal and religious, and often the two 
were not unconnected, that is to say that these Celtic-speaking lands were dominated by hierarchies of polities which can be described loosely as kingdoms and whose rulers therefore claimed royal status. Thus, for example, in the early post-Roman centuries (the sixth and seventh centuries), each Irish túath (lit. people), which in some cases probably extended to an area not more than a few square miles, was ruled by a king (rí túaithe) and constituted a kingdom. Furthermore, these lesser kings, like the higher grades of king, were members of dynasties, all of whose members could accordingly claim royal - if not specifically kingly - status. Consequently, the fundamental unit for political association and power for our present purposes was the kingdom or, more significantly, the dynasty and membership thereof. These kingdoms might expand (or contract) in terms of territory, and in some cases even shift their focus over time, or a dynasty could extend its sphere of influence by exerting overlordship of a number of neighbouring kingdoms (and ultimately to the level of the provincial overkingship), and yet the primary unit remained the dynastic kingdom. In terms of planning a prosopography of early Irish secular elites therefore, the main focus will inevitably be on such kings and their dynastic kinsmen.

Furthermore, the character of the religious elite (higher clergy) of early medieval Ireland also had a strongly dynastic, and therefore secular, element. It has long been recognised that control of many of the numerous monastic churches throughout Ireland could lie in the hands of a single clerical family, often with the abbatial succession passing from father to son(s). For example, members of the well-known Clann Shínaig (Descendants of Sínach) dominated the church of Armagh from the mid-tenth into the twelfth century. Furthermore, many of these clerical families were (or claimed to be) genealogically affiliated to one of the local secular dynasties, perhaps representing a cadet or politically unsuccessful segment of this dynasty. Thus, the aforementioned Clann Shínaig were related to the ruling dynasty of the kingdom of Ind Airthir, within whose territory Armagh was situated. Prosopographical study of the religious elites of early medieval Ireland is to some extent therefore a matter of dynastic reconstruction, not too dissimilar from that of secular politics, though (as will be illustrated below) the prosopographical information supplied in the relevant primary sources about the political and religious elites is by no means identical.

As I have discussed elsewhere, there are essentially two types of primary source from which the prosopography of these elites can be studied, namely the medieval chronicles and royal genealogies. ${ }^{1}$ For reconstituting dynastic kinship groups (especially, secular ones, but to some extent certain clerical ones too) and thereby for reconstructing succession patterns, the often very detailed and highly segmented genealogical sources are obviously of value, but in fact in this and other respects, the chronicles can supply important data 
not found in the surviving genealogies. In particular, we have very few genealogies of clerical families and therefore prosopographical information about early Irish churches and their elites are to be found mostly in the chronicles. Consequently, the annalistic and genealogical sources to some extent complement one another. It follows therefore that any proposed prosopographical database of early medieval Ireland should be designed around these two main sources. In addition, however, there are a number of other types of source which can provide useful prosopographical information: for example, regnal and abbatial lists (which are relatively few in number), saints' genealogies and martyrologies, epigraphic sources, and 'saga' narratives.

As stated above, to date there has been no attempt at comprehensive prosopographical studies for the Celtic-speaking regions during the Middle Ages, ${ }^{2}$ although there have been many individual studies which involve what might be termed a prosopographical element or which clearly are relevant to the prosopographer. This statement is both true for recent as well as for earlier research. For instance, given the importance of the genealogies, then it would be necessary to consider the problems of using them as primary sources or, ${ }^{3}$ beyond that, a broader consideration of medieval Celtic kinship as revealed in these and other sources. ${ }^{4}$ Also, at the 'local history' level, there has been, and continues to be, interest in reconstructing the genealogies of local dynasties and families, sometimes using unpublished material, which can certainly be of prosopographical interest. ${ }^{5}$ Furthermore, because we are dealing largely with royal dynasties, then research into the patterns of succession to kingship will obviously serve to illuminate the dynamics of those dynasties. ${ }^{6}$ Similarly, the study of personal names and naming patterns among the early medieval Celts is an area of interest to the prosopographer, though a lot of work to date has been more linguistically than historically orientated. ${ }^{7}$ For the religious elite, similar comments could be made: the reconstruction of abbatial and episcopal succession has been undertaken for many important churches, ${ }^{8}$ but the fuller prosopographical study of particular houses or for the whole region is still awaiting to be undertaken on any significant scale. ${ }^{9}$ It should be stated that, despite the comments made above, there is a good number of recent individual studies, especially for secular subjects, which can be described as prosopographical in character. ${ }^{10}$ Finally, it must be stressed that very little recent research in this area has involved the active use of computer technology. There are exceptions to this, such as the Corpus of Electronic Texts (CELT) project based at the University of Cork or the Celtic Inscribed Stone Project (CISP) based at the University of London, but this relative lack of computer applications is to be regretted since, as I will endeavour to demonstrate below, a large amount of source-material from the Celtic early Middle Ages does lend itself quite readily to analysis by computers, especially from a prosopographical perspective. $^{11}$ 
I am currently working on a long-term prosopographical study of early medieval Ireland, which includes the design and use of a prosopographical database; and the remainder of this article will discuss some of the main elements (and problems) of this research. It should be added that the work is still in its infancy but a sufficient amount has been completed to permit the illustration of a number of important points.

\section{CONTENT ANALYSIS AND IMPLICATIONS}

As stated above, the two most important types of primary source for the prosopographical study of early medieval Ireland are the annalistic and genealogical texts and consequently it is these sources which should form the basis of any planned database. Since the design of an historical database should begin by considering what are the categories of information (in this case, prosopographical) contained within the relevant documents and which will dictate the particular 'fields' of a database, it will be useful here to offer a content analysis of the relevant Irish sources. Furthermore, in my own work I have started with the chronicles, and so I propose to illustrate this work by drawing upon an annalistic example here. Specifically, I will examine the socalled 'Annals of Ulster' (one of the most important medieval Irish chronicles) for the year 788 (in translation): ${ }^{12}$

\section{Kalends of January [ ] A.D. 977 alias 978.}

1. Fiachra, erenagh [abbot] of Iona, rested.

2. A battle between Brian mac Cennétig and Mael Muad, king of Desmumu, in which Mael Muad fell.

3. The battle of Bithlann [was won] over the Laigin by the Foreigners of Dublin, in which fell the king of Laigin, namely Úgaire mac Tuathail, and many others.

4. A battle-rout [inflicted] by the Airgialla on the Cenél Conaill in which fell Niall ua Canannáin and many others.

5. Cork of Munster was sacked by fire.

6. Lismore of Mo Chutu was plundered and burned.

As this sample indicates, for our purposes, it is possible to analyse the events recorded in the annals into two main types. Firstly, there are what might be termed 'anonymous' events, describing notable natural or sometimes miraculous phenomena or human-caused events relating to particular places (the plundering and burning of the church at Lismore and the conflagration of the church at Cork above). Such entries may be very important in terms of what they describe but, since they are 'anonymous', they have less value 
prosopographically. On the other hand, most of the events related in the chronicles are concerned with named individuals - most are Irish men (in which category I would include 'Hiberno-Scandinavians' or Irish vikings), but there are also a few references to famous non-Irish figures and also a small number to Irish women. Obviously, it is such named individuals who will form the basis of a prospective database. The next question, therefore, must be: what are the main and relatively consistent 'categories of information' concerning the individuals named in the chronicles which may form the fields of this proposed database? ${ }^{13}$

Fortunately, and despite the clearly narrative character of the chronicles, the format and content of most annal-entries for the early Middle Ages are fairly regular so that, I would argue, the designing of a database structure is certainly feasible. Firstly, all chronicles are organized chronologically into separate annals for successive years - some, as in the example above, are assigned Anno Domini dates, though these may not necessarily be the correct dates (in the example above, a later scribe has added the 'correct' year); other chronicles lack absolute dates but indicate new years using $\mathrm{Kal}$ ' ('calends'), in which case the modern editor can possibly reconstruct the underlying chronological scheme. Secondly, since we are concerned with a prosopographical database, then the anthroponymic information contained in the annal-entries is important. Now, there are a number of potentially complicating factors which must be taken into account here. The vast majority of individuals are referred in the chronicles to by their forename (for example, Fiachra or Brian above). They may then be further distinguished by means of a patronymic: this was usually in the form mac ('son') plus father's name in the genitive case (for instance, mac Cennétig, 'son of Cennétig' above); but, sometimes it was ua ('grandson') plus grandfather's name (ua Canannáin, 'grandson of Canannán', above, but see below). Very occasionally, perhaps both father and grandfather would be included, thus supplying three generations. Furthermore, by the late tenth century and especially during the eleventh, we see the beginnings of a shift towards the use of hereditary surnames derived from the two types of patronymic described here: in the example above, the form Niall $U a$ Canannáin, 'Niall O'Canannán', is perhaps be preferred though the text itself gives no indication of this. Finally, certain figures are also assigned a nickname (no examples above). Patronymics and nicknames are more commonly attested for secular figures than for clerics: thus, the churchman Fiachra above lacks such additional onomastic information. ${ }^{14}$ Thirdly, many persons are given a 'title', which can be analyzed as consisting of two parts: the relevant status or position (for example, rex or rí, 'king', or a lesser status for other secular figures, and eccelesiastical positions such as abbas or episcopus or their Gaelic equivalents); and then, the name of the kingdom or dynasty (for laymen) or of the relevant church (for clerics). This pattern is relatively consistent in 
the chronicles though difficulties may arise when an individual is credited with more than one title or in the very rare instances when a king also held a clerical position. These then are the basic categories of information supplied relatively consistently, if not invariably, for individuals who occur in the chronicles: the date, the anthroponymic material (of various types), and the title (including status and also political or ecclesiastical association). In addition, the sex of the person can usually be determined from the forename or the patronymic (mac, 'son' vs. ingen, 'daughter') and, even in cases where the title is omitted, clerical status may be inferred from the context or from certain words or phrases (e.g., an abbot or bishop was more likely to dormiuit or pausauit in pace than was a king).

As well as these basic categories of information, there remains the most variable element of the annal-entries, namely the 'event' itself in which, perhaps naturally, we will expect the highest degree of variety in terms of information and therefore most difficulty in terms of database design. At present, I would estimate that over 60 per cent (perhaps higher) of individual occurrences in pre-1100 Irish chronicles record deaths, and over half of these were deaths by natural means. Such deaths therefore took the form of simple statements (as in the first entry for 978 above), though very occasionally additional information is supplied about the cause of death ('after a long illness') or age at death (usually for clerics). For deaths by non-natural causes, some entries simply state that the person (who was usually but not necessarily a layman) was killed without any additional comment (iugulatio est); but, in many cases we learn more: for instance, in which battle the person fell (Bithlann, above), against which kingdom he was fighting, by whom he was slain (a neighbouring king, or a dynastic rival: see below), and sometimes even more narrative details may be supplied. The remaining 30 per cent (or less) occurrences of individuals in the chronicles do not record their deaths but instead relate a variety of other activities: for example, succession to a kingdom or abbacy, winning or losing a battle, killing another person (which is of course the other side of the 'killed by whom' coin mentioned above), raiding a neighboring kingdom or church, going on pilgrimage, being imprisoned or blinded by rival dynasts, and so forth. Furthermore, such entries are not always simple statements but can involve more than one sentence describing a series of causally connected events or sub-events. Obviously it would be difficult to analyze such material effectively for the purposes of database design and I will suggest below that the 'events' must be accounted for less rigidly.

\section{PROVISIONAL DATABASE DESIGN}

In the light of the foregoing discussion, it would seem possible to accommodate most of the information of prosopographical interest from the chronicles 
within a flat-format database, though certain elements may require careful consideration. The main prosopographical fields would be as follows:

- Date (Text): this would be the year according to the original text;

- Date (AD): this would be the (probable) 'correct' date;

- Forename;

- Nickname;

- Father: this would be the patronymic based on mac;

- Grandfather: as above, but using mac or $u a$ according to the text;

- Surname;

- Status: the position held, perhaps using coded abbreviations;

- Kingdom: the name of the kingdom or dynasty of a layman; $;^{15}$

- Church: the name of the church of a cleric;

- Cleric: if a cleric, tick;

- Woman: if a woman, tick;

- Event: an abbreviation system for indicating broad category of event. ${ }^{16}$

Table 1 shows the tabulation and coding from the sample from the Annals of Ulster given above.

One obvious problem in terms of efficiency of design is the large number of 'blanks' for the onomastic fields. This is unavoidable because, as explained above, the anthroponymic information supplied in the chronicles can vary significantly and because reducing it all to a single field would reduce the effectiveness of searching and sorting. Furthermore, keeping the different types of onomastic data separate would be useful when integrating the annalisticbased tables with tables based on the genealogies and when attempting to identify the individuals named therein. Lastly, the tabular scheme described here does not adequately deal with the problem of the more narrative annal - entries, that is entries which are more complicated than mere obit-records. There are two possible ways of accommodating such material: either by means of an additional 'memo' field, or by using a separate but 'related' file which would record the full text (in the original language) for each year/annal.

As argued above, it would seem best to begin a prosopographical database of early medieval Ireland using the chronicles and, to date, I have followed the scheme outlined here, using Microsoft Access, for most of the extant and published annalistic texts for the period 700-1050 (only one text, the so-called 'Fragmentary Annals of Ireland', is yet to be databased). In addition, I have started compiling a 'master table', combining and comparing material from the different chronicles in order to identify more explicitly the individuals named therein. This latter task is slow and fraught with difficulty due to discrepancies between the different texts, both for chronological and onomastic information, and consequently it seems prudent to restrict such interpretative 


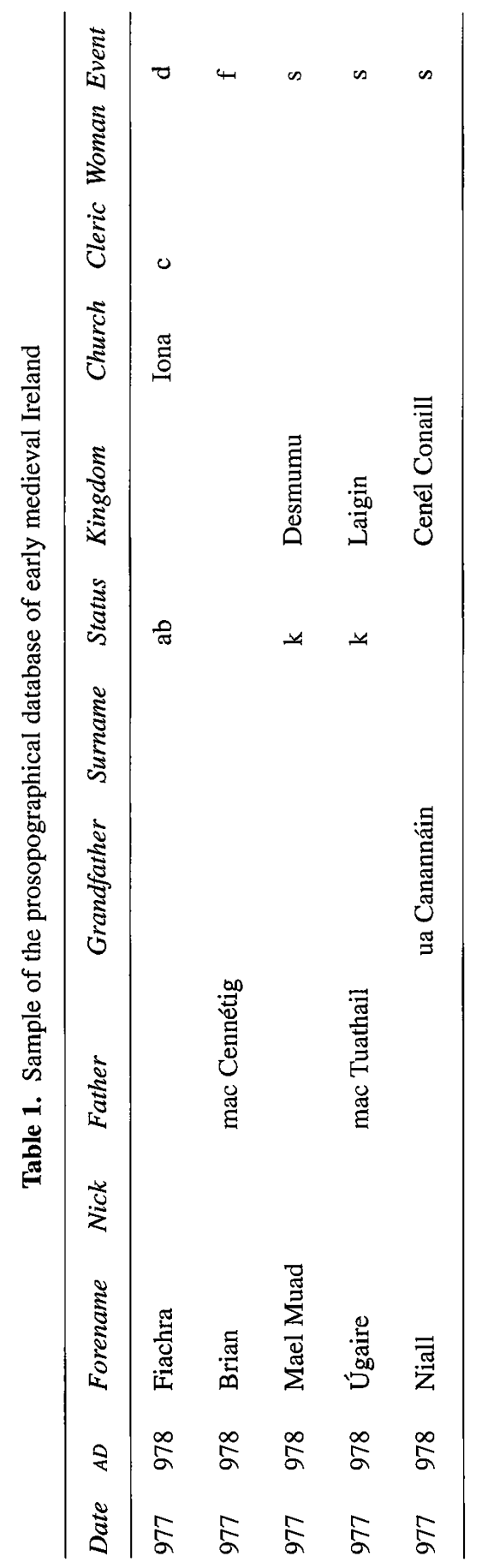


work to this separate file and so leave the individual chronicle's tables untouched.

In the near future, it will be necessary to begin databasing the royal genealogies though this will certainly be a time-consuming task due to the amount and complexity of the extant genealogical material (both published and, more importantly, unpublished). The royal genealogies comprise two main types, both of which lack any absolute dating: ${ }^{17}$ simple pedigrees or 'retrograde patrilines' (of the type $\mathrm{X}$ son of $\mathrm{Y}$ son of $\mathrm{Z}$ etc.) giving one name per generation; and, segmentary genealogies which may list more than one name for each generation (thus, A had three sons: B, C, D; B son of A had one son, E; and, C son of A had two sons, F and G; etc.). Provisionally, I would suggest that such material could be tabulated in the following fields:

- Reference: edition or manuscript reference for the individual genealogy;

- Kingdom/Dynasty: most genealogies have a title;

- Forename;

- Father: this would be the patronymic based on $m a c ;^{18}$

- Grandfather: this would be the father's patronymic based on the mac;

- Sons: names of any sons given in the relevant genealogy;

- Notes: a memo field for any additional information given in the text;

This would therefore allow for up to four generations to be included in each entry in the table, which ought to be sufficient in most cases to avoid confusing namesakes and to facilitate identification with figures named in the chronicles. However, I have not yet started working on the genealogies, so these comments must remain provisional.

In addition to the genealogies, it will eventually become necessary to incorporate the other relevant types of sources listed above. For instance, the regnal and abbatial lists, as well as the prose and verse texts known collectively as Banshenchas, ${ }^{19}$ will serve to supplement the chronicles and royal genealogies. Furthermore, if the annalistic database is to be extended backwards to cover the proto-historical period $\mathrm{AD} 500-700$, then certainly the saintly genealogies ${ }^{20}$ and martyrologies ${ }^{21}$ would need to be used because this was the time when most Irish saints flourished. Evidently, there remains much to be done in the designing and development of this database; and yet, it is hoped that this short account has served to demonstrate that a computer-based prosopography of early medieval Ireland is certainly a viable project which will go some way to addressing the relative lack of research in this field of historical study. 


\section{NOTES}

${ }^{1}$ D. E. Thornton, 'Kings, chronicles and genealogies: reconstructing mediaeval Celtic dynasties', in K. S. B. Keats-Rohan, ed., Family trees and the roots of politics (Woodbridge, 1997), 23-40. Cited here at 25. D. E. Thornton, Kings, chronologies and genealogies. Studies in the political history of early medieval Ireland and Wales (Forthcoming), Chs. 2-3.

2 Possible exceptions to this claim would include (for Wales during one century) K. L. Maund, Ireland, Wales, and England in the eleventh century (Woodbridge, 1991), and (for one Irish region) A. P. Smyth, Celtic Leinster: towards an historical geography of early Irish civilization A.D. 500-1600 (Blackrock, 1982).

${ }^{3}$ D. Ó. Corráin, 'Irish origin legends and genealogy: recurrent aetiology', in T. Nyberg et al., eds, History and heroic tale (Odense, 1983), 51-96; D. Ó. Corrain, 'Creating the past: the early Irish genealogical tradition', Peritia: Journal of the Medieval Academy of Ireland, 12 (1998), 177-208; K. McCone, Pagan past and Christian present in early Irish literature (Maynooth, 1990), 233-55; D. E. Thornton, 'Orality, literacy and genealogy in medieval Ireland and Wales', in H. Pryce, ed., Literacy in medieval Celtic societies (Cambridge, 1998), 83-98; D. E. Thornton, 'Power, politics, and status: aspects of genealogy in mediaeval Ireland and Wales' (unpublished Ph.D. thesis, University of Cambridge, 1991).

${ }^{4}$ T. M. Charles-Edwards, Early Irish and Welsh kinship (Oxford 1993); N. T. Patterson, Early Irish kinship. The legal structure of the agnatic descent group (Boston, MA, 1988); N. T. Patterson, Cattle-lords and clansmen. The social structure of early Ireland, 2nd ed. (Notre Dame and London, 1994); N. T. Patterson, 'Patrilinear kinship in early Irish society: the evidence from the Irish law tracts', Bulletin of the Board of Celtic Studies, 37 (1990), 133-65.

${ }^{5}$ D. N. Dumville, 'The "six" sons of Rhodri Mawr: a problem in Asser's Life of King Alfred', Cambridge Medieval Celtic Studies, 4 (1982), 5-18; S. Ó Néill, The O'Neills of Leinster. An investigation into the origins of the O'Neills of Magh Dá Chonn - Moycomb Leinster (Belfast, 1992); D. E. Thornton, 'A neglected genealogy of Llywelyn ap Gruffudd', Cambridge Medieval Celtic Studies, 23 (Summer 1992), 9-23; D. E. Thornton, 'The genealogy of Gruffudd ap Cynan', in K.L. Maund, ed., Gruffudd ap Cynan (Woodbridge, 1997), 79-108; D. E. Thornton, 'Clann Eruilb: Irish or Scandinavian?', Irish Historical Studies, 30 (1996), 161-6; D. E. Thornton, 'Early medieval Louth: the kingdom of Conaille Muirtheimne', County Louth Archaeological and Historical Journal, 24/1 (1997), 139-50; S. P. Thomas, 'The genealogy of Brochwel ab Aeddan', Transactions of the Honourable Society of Cymmrodorion (1982), 25-8.

${ }^{6}$ M. O. Anderson, Kings and kingship in early Scotland, 2nd ed. (Edinburgh, 1980); J. B. Smith, 'Dynastic succession in medieval Wales', Bulletin of the Board of Celtic Studies, 33 (1986), 199-232; B. Jaski, Early Irish kingship and succession (Dublin, 2000).

7 B. Ó. Cuív, 'Aspects of Irish personal names', Celtica, 18 (1986), 151-84; N. Ó Muraíle, 'The Irish genealogies as an onomastic source', Nomina, 16 (1992-3), 23-47; D. E. Thornton, 'Predatory nomenclaure and dynastic expansion in early medieval Wales', Medieval Prosopography, 20 (1999), 1-22; D. E. Thornton, 'Names within names: hagiophoric and toponymic anthroponymy in early medieval Ireland', in K. S. B. Keats-Rohan and C. Settipani, eds, Onomastique et parenté dans l'occident medieval (Oxford, 2000), 267-82; D. E. Thornton, 'Hey, Mac! The name Maccus, tenth to fifteenth centuries', Nomina, 20 (1997), 67-94.

${ }^{8}$ F. J. Byrne, 'Heads of churches to c.1200', in T. W. Moody et al., eds, A new history of Ireland, 9 vols (Oxford, 1982- ), IX, 237-63.

9 A. S. Mac Shamhráin, Church and polity in pre-Norman Ireland. The case of Glendalough (Maynooth, 1996); D. Ó. Corráin, 'The early Irish churches. Some aspects of organization', in D. Ó Corráin, ed., Irish antiquity. Essays and studies presented to Professor M. J. Kelly (Cork, 1981), 327-41. For a still useful guide to medieval Irish clerics and saints, see J. F. Kenney, The sources for the early history of Ireland: I. Ecclesiastical (New York, 1929; rev, imp., Dublin, 1993).

${ }^{10} \mathrm{~S}$. Duffy, 'Ostmen, Irish and Welsh in the eleventh century', Peritia: Journal of the Medieval Academy of Ireland, 9 (1995), 378-96; K. Jackson, 'Gildas and the names of the 
princes', Cambridge Medieval Celtic Studies, 3 (1982), 30-40; H. R. Loyn, 'Wales and England in the tenth century: the context of the Athelstan charters', Welsh History Review, 10 (1980-1), 283-301; K. L. Maund, 'Trahaearn ap Caradog: legitimate usurper?', Welsh History Review, 13 (1986-7), 468-76; D. E. Thornton, 'Edgar and the eight kings, AD 973: textus et dramatis personae', Early Medieval Europe, 10 (2001), 49-79; D. E. Thornton, 'Maredudd ab Owain (d. 999): most famous king of the Welsh', Welsh History Review, 18 (1996-7), 567-91; D. E. Thornton, 'The death of Hywel Dda: a note', Welsh History Review. 20 (2001), 743-9; D. E. Thornton, 'Who was Rhain the Irishman?', Studia Celtica, 34 (2000), 131-48; L. Cox, 'The Briens of Brawney otherwise Uí Braoin Breaghmhaine', Ríocht na Midhe, 7/1 (1980-1), 80-98; K. Nichols, 'The MacCoghlans', Irish Genealogist, 6 (1980-5), 445-49; D. M. Schlegel, 'The MacDonnells of Tyrone and Armagh. A genealogical study', Seanchas Ardmhacha, 10 (1980-2), 193-219; D. Sproule, 'Origins of the Éoganachta', Ériu, 35 (1984), 31-38; R. M. Sweeney, 'The origins of Clann Suibhne', Donegal Annual, 42 (1990), 61-2.

1 CELT. Corpus of electronic texts [World Wide Web search interface]. <URL: http:// www.ucc.ie/celt> [27 June 2001]; Celtic inscribed stones project [World Wide Web search interface]. <URL: http://www.ucl.ac.uk/archaeology/cisp/database> [27 June 2001].

${ }^{12}$ S. Mac Airt and G. Mac Niocaill, eds, The annals of Ulster (to AD 1131) (Dublin, 1983), 412-15 (for text and translation).

${ }^{13}$ For a fuller account of the following material, see Thornton, Kings, chronologies and genealogies, esp. Ch. 3.

14 The Annals of the Four Masters, a late but important annalistic source, does add ua Artacáin (grandson of Artacán) in its equivalent entry.

15 Very occasionally, the chronicles do supply the name of the kingdom or dynasty to which a cleric belonged, mostly commonly in the case of members of the important community at Clonmacnoise.

${ }^{16}$ For example, f(loruit), d(ied), s(lain), and b(orn) (the latter would be very rare however).

${ }^{17}$ The problem of dating for the genealogies is a serious one: many of the pedigrees especially reach back to pre-historic and legendary levels and, without absolute dates, it is therefore more difficult to control their chronological range with any certainty than it is for the chronicles.

${ }^{18}$ In both the father and grandfather fields, I would use ' $\mathrm{m}$.', which is the abbreviated form commonly used in the manuscripts for both mac and the genitive maic or meic.

19 These record the maternal ancestry of some (but certainly not all) early medieval kings and provide useful information about inter-dynastic marriage.

20 These are conveniently available in a single volume, P. Ó. Riain, ed., Corpus genealogiarum sanctorum Hibernie (Dublin, 1985), which includes individual pedigrees plus other 'documents' such as lists of saintly namesakes.

${ }^{21}$ I have experimented with one early text, the so-called Martyrology of Tallaght, which demonstrated that martyrologies could be readily databased in a tabular format. 